\title{
ROLE OF MEN IN WOMEN'S HEALTH STATUS IN RURAL AREAS OF ANDHRA PRADESH
}

\author{
Usha Rani Chadalawada1, Sudha Kumari P2, Sandhya Rani M³
}

1 Professor, Department of Community Medicine, Government Siddhartha Medical College, Vijayawada.

${ }^{2}$ Associate Professor, Department of Community Medicine, Guntur Medical College, Guntur.

3Postgraduate, Department of Community Medicine, Government Siddhartha Medical College, Vijayawada.

ABSTRACT

\section{BACKGROUND}

In commemoration of World Population Day 2011 with the Under Theme 'Men as Partners in Maternal Health.' Given the importance of the male role in the Indian context in the family decisions which is inclusive of women's reproductive health and family size led to undertake this study to assess their care or role in women's health in the underserved areas of Andhra Pradesh.

The study is to assess the health status of women aged 18-45 years, elicit the men's awareness and response of men regarding their wives' health status and to determine if both the responses are in conformity.

\section{MATERIALS AND METHODS}

Hundred families were randomly selected within $15 \mathrm{kms}$ of Bapatla town of Guntur and Prakasam districts.

\section{RESULTS}

Over $60-65 \%$ of women in the age group did have one or the other health problems like anaemia, dysfunctional uterine bleeding, pregnancy and related health needs; $70 \%$ of men were aware that their wives were unwell; $20-25 \%$ of men went to the hospital with their wives and took responsibility of home care. Over $75 \%$ of men decided which hospital to go to and family size decision. Nearly, $92 \%$ of men did not know about the safe period.

\section{CONCLUSION}

Despite the fact that majority of women are unwell and men being aware, little favourable response observed. This needs to be gently worked on to involve men for better women's health.

\section{KEYWORDS}

Role, Men, Women's Health Status, Rural Area.

HOW TO CITE THIS ARTICLE: Chadalawada UR, Kumari SP, Rani SM, Role of men in women's health status in rural areas of Andhra Pradesh. J. Evolution Med. Dent. Sci. 2016;5(86):6429-6431, DOI: 10.14260/Jemds/2016/1454

\section{BACKGROUND}

Men's support is an essential component for making women's world better, be it during pregnancy, child caring and rearing and household chores. In a study by Becker S, reproductive health interventions that target couples are found to be more effective than those directed to only one sex. The evidence clearly justifies a focus on couples.[1] In a study by Bankole A, fertility desires of couples are important predictors of a couple's fertility.[2] Importance of men's role in improvement of women's health is now well accepted.

As per the study by Bancole A, the three measures of reproductive attitudes are subject to different degrees of measurement error. The measure of reproductive intentions is the most consistent of the three, followed by ideal number of children. The latter is much more consistent at the aggregate level than at the individual level. The reliability of the planning status of the last birth is marred, mainly by an unwanted child being reclassified as 'wanted' with time since the birth of the child.

The reproductive intentions of women were also found to be positively related to their subsequent fertility.[3] While international family planning programs were essentially about women's health, reproductive health as it has now been formulated goes beyond health to broader development issues.[4] "Special efforts should be made to emphasise men's shared responsibility and promote their active involvement in responsible parenthood, sexual and reproductive behaviour including family planning; prenatal, maternal and child health; prevention of STDs including HIV; prevention of unwanted and high-risk pregnancies; shared control and contribution to family income, children's education, health and nutrition; and recognition and promotion of the equal value of children of both sexes," was the statement included in the 1994 International Conference on Population and Development in Cairo, Program of Action on "Male Responsibilities and Participation." The same message was reinforced at the 1995 World Conference on Women in Beijing. [4]
\end{abstract}

Financial or Other, Competing Interest: None.

Submission 03-05-2016, Peer Review 15-10-2016,

Acceptance 22-10-2016, Published 27-10-2016.

Corresponding Author:

Dr. Usha Rani Chadalawada,

Professor,

Department of Community Medicine,

Government Siddhartha Medical College,

Viyayawada-520008.

E-mail: gurneeshellora@yahoo.co.in

DOI: $10.14260 / \mathrm{jemds} / 2016 / 1454$

\section{MATERIALS AND METHODS \\ Type of Study}

Cross-sectional observational study.

\section{Area of Study}

$15 \mathrm{kms}$ around Bapatla (Guntur and Prakasam districts).

\section{Study Population}

Randomly selected 100 families. 


\section{Sample Size}

Population residing in the study area was around 30,000 families. Total 100 families were taken into study after taking consent.

\section{Sampling Method}

Simple random sampling by lottery method. The area was divided into 5 subareas and every $5^{\text {th }}$ house was selected in the respective subareas in the study after taking consent. Thus, a total of 100 families were included through simple random sampling.

\section{Methodology}

Trained social workers from the area were involved and oriented to the current study and were monitored, while administering the instrument and documentation. The eligible couples in the families were administered a questionnaire separately to the women and her husband, constituting all the common ailments of women in reproductive age including puberty, safe period, family planning measures, menstrual disturbances, pregnancy and related care through all phases, lactation, puerperal care, family planning, family welfare, safe period and desired family size.

Study instrument: Pre-tested Semi-structured Questionnaire.

\section{Data Collection and Analysis}

Observations obtained were tabulated and findings were subjected to statistical analysis. Statistical analysis was done using MS Excel ver. 2010 and SPSS Software ver. 16

\section{RESULTS}

\begin{tabular}{|l|c|}
\hline 1. Age & Percentage \\
\hline $18-24$ & $84 \%$ \\
$25-45$ & $16 \%$ \\
\hline 2. Education & \\
Illiterate & $72 \%$ \\
Literate & $28 \%$ \\
& \\
\hline 3. Occupation & \\
Home maker & $94 \%$ \\
Working woman & $6 \%$ \\
& \\
\hline 4. Religion & $68 \%$ \\
Hindu & $15 \%$ \\
Muslim & $17 \%$ \\
Christian & \\
\hline 5. Socio-economic status & $5 \%$ \\
Lower class & $52 \%$ \\
Lower middle class & $33 \%$ \\
Middle class & $10 \%$ \\
\hline Upper middle class & \\
\hline \multicolumn{2}{|c|}{ Table 1. Socio-Demographic Profile of Women } \\
\hline
\end{tabular}

\begin{tabular}{|l|c|}
\hline Sociodemographic Variable & Percentage \\
\hline Age & $30 \%$ \\
$18-24$ & $28 \%$ \\
$25-31$ & $18 \%$ \\
$32-38$ & $24 \%$ \\
38 \& above & \\
\hline Education & $33 \%$ \\
Illiterate & $67 \%$ \\
Literate & $13 \%$ \\
\hline Occupation & $44 \%$ \\
Unemployed & $23 \%$ \\
Daily labourer & $20 \%$ \\
Semiskilled worker & \\
Skilled worker & Table 2. Sociodemographic Profile of the Husbands \\
\hline \multicolumn{2}{|c|}{}
\end{tabular}

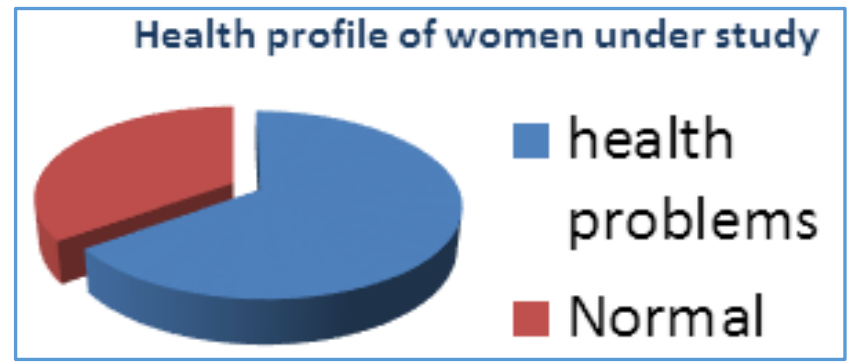

Figure 1. Pie Diagram showing the Health Profile of the Women Under Study

Over $65 \%$ of women in the age group of $18-45$ years did have one or the other health problems like anaemia, dysfunctional uterine bleeding, pregnancy and related health needs.

\begin{tabular}{|c|c|}
\hline Men's Role in Women's Health & $\%$ \\
\hline Men aware of women's health status & $70 \%$ \\
\hline $\begin{array}{l}\text { Responsibility taken by men to accompany } \\
\text { wives to hospital }\end{array}$ & $25 \%$ \\
\hline Unaware of safe period & $92 \%$ \\
\hline Decision of family size taken by men & $75 \%$ \\
\hline
\end{tabular}

\section{DISCUSSION}

The current study shows around $65 \%$ of women in the age group did have one or the other health problems like anaemia, dysfunctional uterine bleeding, pregnancy and related health needs. Our study showed that $70 \%$ of men were aware that their wives were unwell; $20-25 \%$ of men went to the hospital with their wives and took responsibility of home care.

In a study by White $\mathrm{D}$, the preferences and opinions of mothers-in-law were associated with the maternal health behaviours of their daughters-in-law. Women's own perceptions of their self-efficacy, the value of women in society and the quality of services at the local health facility were also independently associated with their preventive and health-seeking practices. Husbands' preferences and opinions were not associated with any outcome.[5]

Our study found that $75 \%$ of men decided which hospital to go to and family size decision. This finding is close to the study done by Azuh D, Fayomi $\mathrm{O}$ and Ajayi which found that in family decision making power including that of health and 
treatment place, the patriarchal domination orchestrated by gender roles manifested prominently as husband exercises an overwhelming proportion $(72.7 \%)$ or control in the affairs of his household activities.[6]

\section{CONCLUSION}

In conclusion, it is found that despite the fact that majority of women are unwell and men being aware, little favourable response observed. This needs to be gently worked on to involve men for better women's health. Need for men to involve and take part in understanding and safeguarding services for women. Though there might be social, cultural barriers that man is the head of the family and not to worry about the female health aspects is no longer viable. It needs a complete turnaround perspective that men should be aware of the female health aspects and physiological changes as it occurs in men. This helps in understanding the safe period, know the concept of family size, as here it is determined by the male or other elders in the family which is not desirable.

In a study by Abhilasha Sharma, inadequate information about male methods of family planning, lack of awareness about the advantage of vasectomy over tubectomy and safety, limited access to vasectomy were the reasons of lack of involvement of men.[7] Also importantly the local community needs to be involved, that is what is done in this context of the study to create awareness amongst the common gathering under the name of women empowerment. The outcome relatively helps in developing a more positive and integrated approach to ensure reproductive health services.

In the study Green ME et al, communicated that all policies and programs, information and services need to reflect the social realities of how men and women relate and how this affects their health.[4] In the study by Owumi Bernard patriarchal system is dominant, $80 \%$ respondents husbands had the final say.[8] The key message is men can play bigger role and make families happy if the women of the house's silent reproductive health aspects are addressed necessarily.

\section{Limitations of the Study}

As there was not enough literature in India related to the topic of study, current study was initiated and proposed to cover the entire area phase wise.

\section{REFERENCES}

1. Becker S. Couples and reproductive health: a review of couple studies. Studies in Family Planning 1996;27(6): 291-306.

2. Bankole A. International fertility and fertility behaviour among the Yoruba of Nigeria: a study of couple preferences and subsequent fertility. Population Studies 1995;49(2):317-28.

3. Bankole A, Westoff CF. The consistency and validity of reproductive attitudes: evidence from Morocco. Journal of Biosocial Science 1998;30(4):439-55.

4. Greene ME, Mehta M, Pulerwitz J, et al. Involving men in reproductive health: contributions to development. www.unmillenniumproject.org/documents/Greene_et_al -final.pdf 2006.

5. White D, Dynes M, Rubardt M, et al. The influence of intrafamilialpower on maternal health care in Mali: perspectives of women, men and mothers-in-Law. International Perspectives on Sexual and Reproductive Health 2013;39(2):58-68.

6. Azuh D, Fayomi 0, Ajayi L. Socio-Cultural factors of gender roles in women's healthcare utilization in southwest Nigeria. Open Journal of Social Sciences 2015;3(4):105-117. http://dx.doi.org/10.4236/jss.2015.34013.

7. Sharma A. Male involvement in reproductive health: womens perspective. The Journal of Family welfare. 2003:49(1):1-8.

8. Owumi B, Sakiru RO. Socio-Cultural determinants of maternal health care seeking behavior in seme side of benin republic. African Journal of Social Sciences 2013;3(1):145-58. 